\title{
Introduction: The economic and social aspects of the family life-cycle in traditional and modern Japan
}

\author{
OSAMU SAITO*
}

Since the publication of the seminal book of essays Household and family in past time in $1972,{ }^{1}$ much research on the history of the family has concentrated on the situation in western and eastern Europe, and relied almost exclusively on census-type documents. It is, for example, established that whereas mean household size was small, the mean age at first marriage fairly high and neo-localism (the formation of an independent household on marriage) dominant in western Europe, almost the opposite applied in eastern Europe. Yet these findings do not preclude the possibility of discovering regions where in statistical terms the mean household size was not large and the proportion of complex households not particularly high, but where the neo-local mode of household formation was not the norm. Such a region could have a preference for joint families (two or more married sons co-residing with their father) with a low-fertility demographic regime, or stem families (one co-residing married son) with that of intermediate to low fertility.

Traditional Japan is an example of just such a stem-family society. There the household, not the individual, was perceived as the basic social and legal unit of society. This unit was called $i e$ and its headship, authority and property were expected to be handed down from the father to a particular son, enabling the household to follow alternating stages of 'simple', 'multiple' and 'extended' forms over the developmental cycle,

Institute of Economic Research, Hitotsubashi University. 
more or less in accordance with the predictions of Lutz Berkner. ${ }^{2}$ As articles in the section of Laslett and Wall's Household and family on Japan have already shown, ${ }^{3}$ the mean household size in eighteenth- and nineteenth-century Japan was not higher than that in England, but the mean age at marriage was lower than in the English population. Moreover, household formation and succession rules under the Japanese ie system were not compatible with the simple family mode.

The essays in this special issue of Continuity and Change are all concerned with aspects of the family life-cycle in this stem-family country in both traditional and modern periods - topics which have attracted much attention from the historians of the family since 1972 . How did the Japanese system of the stem family work? This is in a sense the Hajnal question ${ }^{4}$ with respect to historic Japan but, at the same time, life-cycle issues are likewise involved in it. Indeed, how the size and composition of the household changed over its life-cycle stages, how the household could survive crises occurring during its life course, how the household adapted its size and composition at a time of crisis in order not to become extinct - these are the questions addressed in the essays by Osamu Saito and Masao Takagi in this issue.

To conduct such work, information derived from single census-type listings is not sufficient. Temporal comparison is required in terms of both size and composition of the same household. The village population register called shumon aratame-cho allows such evaluation for Japan in the Tokugawa period (1603-1868). Since it is a census-type listing of villagers taken yearly over a long period of time, ${ }^{5}$ it is possible, for example, to examine how frequently the structure of the household became more complex at one stage of the life-cycle and less complex at another. The analysis can be done in a matrix format, from which the probability of a change of a particular type can be calculated. Results of such exercises, summarized in my own contribution, enable us to identify the typical family life-cycle pattern of the Japanese stem household. My article also gives an overview of studies on nuptiality and household formation that are based on the analysis of village population registers.

More research, of course, can be done with this superb historical record. Household studies may be combined with more demographic analysis in order to exploit the richness of the data. For example, one can estimate the differential probabilities of death for household members: male and female, children and adult, movers and stayers, and so on. One may also assess the impact of the death of the father on the other members of the household, by controlling for external factors such as grain prices. Indeed, these issues are being pursued by scholars involved in the ongoing 
EurAsian Project on population and family history in comparative perspective. ${ }^{6}$

It is also possible to trace individual households from their 'birth', or to their 'death', or occasionally over their whole 'life span'. Because the household is a fusion of residential, consumption and at times production interests, the birth and death of a household are not easy events to define. Reinhard Sieder and Michael Mitterauer in their reconstruction of the family life course in pre-industrial rural Austria have traced, by utilizing a series of data similar to the Japanese village population register, the changing use of a particular piece of property rather than the fortunes of individual kin groups. ${ }^{7}$ Although these authors do not consider it a stemfamily area of the classical type, their approach-based on propertyholding - may be particularly effective for a stem-family society such as traditional Japan. In fact, Takagi in his contribution traces the behaviour of individual households before and after a particular famine period. By comparing those which survived the crisis with those who died out, he argues that the size and composition of the family workforce was crucial for the household to be able to retain property over several generations.

His research suggests that the concept of the family life-cycle involves a consideration of the interrelationships between economic factors and the history of a family. As the size of the family expanded and contracted, the family's property, consumption needs and work patterns also underwent change. This poverty life-cycle was more pronounced for propertyless urban families, as exemplified in the classic study by Seebohm Rowntree of the English town of York at the end of the nineteenth century. ${ }^{8}$ The other two essays in this special issue focus on urban families beneath or close to the poverty line: Kingo Tamai on Osaka and Kiyoshi Nakagawa on Tokyo in the period from the end of the nineteenth to the early twentieth century.

In this respect, consideration needs to be given to how authorities, as well as the family itself, responded to the problem of poverty. In the industrial city of Osaka, according to Tamai, the city authorities' attitude was very different from that of the comparable authorities in Britain and other western-European countries, although the authorities in Osaka did introduce Rowntree's 'poverty line' when urban poverty emerged as a social problem. Targeting the needs of the solitary or widowed poor, rather than extending financial aid to those in the earlier poverty stage of the life-cycle when families had many young children, was viewed as the priority. The assumption underlying this policy was that family and kinship solidarity would work to alleviate poverty, given that the family's income-pooling capacity would function in a way that would raise the 
well-being of the members of the household a little above the poverty line, an assumption that was probably inherited from the rural past. This understanding implies that the poor were not always passive even in the poverty stage of the family life-cycle. Indeed, according to Nakagawa, some lower-class families in Tokyo were a little more ambitious. $\mathrm{He}$ demonstrates, from early-twentieth-century budget data, how consumption needs such as food, on the one hand, and 'status-demonstrating' expenditure, such as housing, social and educational expenses, on the other, changed when the family's earnings rose and fell relative to price levels. One of his findings is that newly emerging factory workers and lower-middle-class families did not reduce expenditure on housing and social expenses even when they felt impoverished, suggesting that a desire to maintain their newly attained life styles - distinguishing them from lower-class people such as journeymen and day labourers-was an important factor determining their budget strategies.

Within the scope of a single issue of Continuity and Change, it is impossible to cover all the aspects of the research agenda concerning household and family studies in traditional and modern Japan. Nor is it possible to illustrate how rich the country's primary sources are in relation to the history of the family. However, the four essays assembled for this special issue have demonstrated some of the ways in which historical issues revolving around the notion of the family life-cycle can be addressed.

\section{ENDNOTES}

1 P. Laslett and R. Wall eds., Household and family in past time (Cambridge, 1972).

2 L. K. Berkner, 'The stem family and the developmental cycle of the peasant household: an eighteenth-century Austrian example', American Historical Review 77 (1972).

3 R. J. Smith, 'Small families, small households, and residential instability: town and city in "pre-modern" Japan'; A. Hayami and N. Uchida, 'Size of household in a Japanese county throughout the Tokugawa era'; and C. Nakane, 'An interpretation of the size and structure of the household in Japan over three centuries', all in Laslett and Wall eds., Household and family.

4 See J. Hajnal, 'European marriage patterns in perspective', in D. V. Glass and D. E. C. Eversley eds., Population in history: essays in historical demography (London, 1965), and 'Two kinds of pre-industrial household formation system', in R. Wall, J. Robin and P. Laslett eds., Family forms in historic Europe (Cambridge, 1983).

5 See L. L. Cornell and A. Hayami, 'The shumon aratame-cho: Japan's population registers', Journal of Family History 11 (1986).

6 See, for example, N. O. Tsuya and S. Kurosu, 'Mortality responses to short-term economic stress and household context in early modern Japan: evidence from two northeastern villages', in T. Bengtsson and O. Saito eds., Population and economy: from hunger to modern economic growth (Oxford, 2000), and S. Kurosu and N. O. Tsuya, 'The mortality effects of adult male death on women and children in households in 
eighteenth and nineteenth century rural Japan: evidence from two northeastern villages', in R. Derosas, M. Oris and O. Saito eds., When dad died: individuals and families coping with family stress (Cambridge, forthcoming).

7 R. Sieder and M. Mitterauer, 'The reconstruction of the family life course: theoretical problems and empirical results', in Wall et al. eds., Family forms.

8 R. S. Rowntree, Poverty: a study of town life (London, 1901). 